\title{
Time-based gene expression programme following diaphragm injury in a rat model
}

\author{
S.N. Mehiri*, E. Barreiro" ${ }^{\#}$, M. Hayot ${ }^{\dagger}$, M. Voyer*, A.S. Comtois $^{+}$, \\ A.E. Grassino* and G. Czaika
}

\begin{abstract}
It was hypothesised that diaphragm injury activates a time-based programme of gene expression in muscle repair.
\end{abstract}

Gene expression of different substances, such as proteases (calpain 94 (p94)), transcription factors (myogenin and cFos), growth factors (both basic fibroblast growth factor (bFGF) and insulin-like growth factor (IGF)-II), and structural proteins (myosin heavy chain (MHC) and titin), was quantified by RT-PCR in rat diaphragms exposed to caffeine-induced injury. Injured and noninjured (control) rat hemidiaphragms were excised at different time points (1-240 h).

In injured hemidiaphragms, in comparison with control muscles, p94 expression levels peaked at $1 \mathrm{~h}$ post-injury (PI), cFos mRNA levels began to rise, after an initial dip, and peaked at $96 \mathrm{~h} \mathrm{PI}$, while myogenin mRNA levels started to increase as early as $12 \mathrm{~h}$ PI, IGF-II mRNA levels initially decreased until $48 \mathrm{~h}$ PI and increased thereafter, peaking at $72 \mathrm{~h}$ PI, bFGF mRNA levels rose to a maximum at $96 \mathrm{~h} \mathrm{PI}$, and $\mathrm{MHC}$ and titin mRNA levels were significantly elevated at $72 \mathrm{~h}$ PI.

Caffeine-induced diaphragm injury is followed by a time-based expression programme of different genes tailored to meet muscle repair needs.

\section{KEYWORDS: Diaphragm, gene expression, injury, repair}

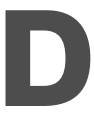
iaphragm fibre injury is associated with reduced muscle force $[1,2]$ that may lead to ventilatory muscle dysfunction. Diaphragm damage is observed both in vitro [3] and in vivo after inspiratory overloading [4-6], sepsis [7], and prolonged mechanical ventilation $[8,9]$. In humans, diaphragmatic sarcomere disruption is more prevalent in patients with chronic obstructive pulmonary disease (COPD) than in healthy subjects [10]. The amount of muscle injury is related to the degree of airway obstruction, and high-threshold inspiratory loading in COPD patients increases the amount of damage $[10,11]$. Based on these findings, it could be hypothesised that diaphragm fibres are able to regenerate efficiently after injury in a similar fashion as limb muscles do when they are repeatedly repaired throughout life [12, 13]. Skeletal muscle regeneration requires activation of quiescent myogenic precursor cells $(\mathrm{mpc})$ that undergo multiple rounds of cell division, differentiate into myoblasts, fuse onto damaged fibres, and, finally, mature into myofibres. Several studies have hinted at a time-based gene expression programme regulating $\mathrm{mpc}$ progression after limb muscle injury, although the contribution of the different molecular mechanisms is not yet well defined [13-15].
In an in vivo rat model [2], it has been shown previously that caffeine-induced diaphragm injury caused sarcolemmal disruption in 33\% of muscle fibres, in association with $70 \%$ muscle force reduction at $1 \mathrm{~h}$ post-injury (PI). Healing of membrane injury was complete by 4 days PI. However, full force recovery only occurred at 10 days PI, suggesting that assembly of sarcomeres and other cellular structures, required for normal force production, takes longer than membrane healing. This supports the concept of a time-based programme, during diaphragm repair, involving the organised expression of different molecular factors, such as proteases, myogenic regulatory factors, growth factors and structural proteins.

The current authors hypothesised that diaphragm injury activates a time-based programme of gene expression in muscle repair. Therefore, the main objectives were to study the time course of mRNA expression of genes involved in different stages of the muscle regeneration process, namely, proteases (calpain 94 (p94)), transcription factors (cFos and myogenin), growth factors (basic fibroblast growth factor (bFGF) and insulin-like growth factor (IGF)-II), and structural proteins (myosin heavy chain (MHC) and titin).

\section{AFFILIATIONS}

*Laboratoire de physiologie respiratoire, Centre hospitalier de I'Université de Montréal (CHUM), Hôpital Notre-Dame, and +Département de Kinanthropologie, Université du Québec à Montréal (UQAM), Montréal, QC, and

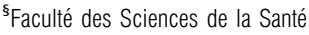
Université d'Ottawa, Ottawa, ON, Canada.

\#Muscle and Respiratory System Research Unit, Institut Municipal d'Investigacions Mèdiques (IMIM) and Experimental Sciences and Health Dept, Universitat Pompeu Fabra (UPF), Barcelona, Spain.

- Service Central de Physiologie Clinique, Centre Hospitalier Arnaud de Villeneuve, Montpellier, France.

CORRESPONDENCE

S.N. Mehiri

CHUM-Hôpital Notre-Dame Room I-2153

1560 Sherbrooke St. East Montreal QC

Canada H2L 4M1

Fax: 15144127519

E-mail: sn.mhiri@umontreal.ca

Received:

April 232004

Accepted after revision:

November 122004

SUPPORT STATEMENT

This study was supported by the Canadian Institutes of Health Research (CIHR-Grant MOP-53119). S.N. Mehiri was the recipient of a Canadian Lung Association-CIHR fellowship. E. Barreiro was supported by SEPAR, FUCAP (Barcelona, Spain) and RESPIRA (RTIC C03/11; Madrid, Spain), and Biomed (BMTH4-CT983406; Brussels, Belgium).

European Respiratory Journal Print ISSN 0903-1936

Online ISSN 1399-3003 


\section{MATERIALS AND METHODS Methodology}

All experiments were conducted on Sprague-Dawley rats (Charles River, St. Constant, QC, Canada) weighing 250$300 \mathrm{~g}$, in accordance with the guidelines of the Canadian Council on Animal Care (Ottawa, ON, Canada) after approval by the institutional Animal Care Committee (Centre hospitalier de l'Université de Montréal (CHUM), Hôpital Notre-Dame, Montréal, QC, Canada). The current authors studied the caffeine-induced injury model that has already been shown to present sarcolemmal damage to $33 \%$ of diaphragm fibres [2].

\section{Experimental procedures}

The rats were anaesthetised by intraperitoneal injection of sodium pentobarbital $\left(50 \mathrm{mg} \cdot \mathrm{kg}^{-1}\right)$. After an aseptic median incision of the abdominal wall, the costal portion of the right hemidiaphragm was exposed to a $100-\mathrm{mM}$ caffeine solution (Sigma Chemicals, St. Louis, MO, USA) dissolved in HEPESbuffered Krebs solution. The caffeine was contained in a $2-\mathrm{cm}-$ diameter plastic suction cup held in place for $10 \mathrm{~min}$ by negative pressure $\left(-20 \mathrm{cmH}_{2} \mathrm{O}\right)$. The same procedure, with a saline-filled suction cup, was applied to the left hemidiaphragm, which served as the control muscle in all rats. The abdominal wall was then closed, and the animals were allowed to recover in cages with food and water ad libitum.

To check whether local caffeine application induces hypoxia, a series of complementary experiments were performed. In 33 adult male rats, oxygen transcutaneous saturation of haemoglobin was measured during the entire time of diaphragm caffeine application $(10 \mathrm{~min})$. None of these 33 animals desaturated.

\section{Study protocol and diaphragm sample preparation}

Nine time-point groups of rats $(\mathrm{n}=7$ each) were established, as has been previously done [2], and sacrificed at 1, 4, 6, 12, 24, 48, 72 , 96 and $240 \mathrm{~h} \mathrm{PI}$, with each animal serving as its own control, since the left hemidiaphragm remained untreated. The diaphragm was removed en bloc, and immersed in equilibrated regular Krebs solution $\left(95 \% \mathrm{O}_{2}, 5 \% \mathrm{CO}_{2}, \mathrm{pH} 7.38\right)$ that was chilled at $4{ }^{\circ} \mathrm{C}$ for further dissection. Both the caffeine and saline-exposed areas were localised and dissected into two portions. One rectangular block was dissected and frozen at $-80^{\circ} \mathrm{C}$ for subsequent molecular biology analysis. The second block was quick-frozen in isopentane, which had been precooled with liquid nitrogen, and preserved at $-80^{\circ} \mathrm{C}$ for histology.

\section{Histological analysis}

Muscle strips (10- $\mu \mathrm{m}$ cross-sections), cut in a cryostat microtome (Leica Cryocut 1800; Leica, Heidelberg, Germany) and maintained at $-20^{\circ} \mathrm{C}$, were stained with haematoxylin and eosin (H\&E) and viewed with a Nikon Eclipse TE600 microscope (Nikon, Melville, NY, USA), which was connected to a Photometrics ${ }^{\circledR}$ CoolSNAP ${ }^{\mathrm{TM}}$ camera (Roper Scientific Inc., Tucson, AZ, USA). Criteria adapted from REID and BELCASTRO [16] were applied to identify abnormal muscle morphology. A muscle area was considered as abnormal when it contained viable muscle with an abnormal morphology, necrotic muscle, or when it was invaded by inflammatory cells (where no outline of muscle cells was evident). Normal and abnormal areas were measured with the area calculator tool of MetaMorph ${ }^{\circledR}$ Imaging System 4.6 software (Universal Imaging Corporation, Downingtown, PA, USA). First, the total cross-sectional area, including normal and abnormal muscle, was computed and displayed in calibrated units. Then, all abnormal areas were delimited with the manual outlining tool, and calculated in a similar manner. The fraction area of abnormal tissue was represented by the percentage of abnormal muscle relative to the total cross-sectional area [17].

\section{Total RNA isolation}

Frozen diaphragm tissue was homogenised (Model 985370 Tissue Tearor; Biospec Products, Bartlesville, OK, USA) in $1 \mathrm{~mL}$ of TRIzol ${ }^{\circledR}$ Reagent (Life Technologies Inc., Rockville, MD, USA) according to the manufacturer's instructions. The extracted total RNA was ethanol precipitated, dried, and resuspended in RNAse-free water before storage at $-80^{\circ} \mathrm{C}$.

\section{RT-PCR analysis}

The oligonucleotide primer pairs used for each of the studied factors are enumerated in table 1 . Purified total RNA ( $1 \mu \mathrm{g}$ per reaction) was the substrate for RT-PCR amplification of gene segments in the Titan ${ }^{\circledR}$ One-Tube RT-PCR System (Roche Diagnostics, Laval, QC, Canada). Each gene-specific fragment was co-amplified with a 237-base pair fragment corresponding to mRNA glyceraldehyde-3-phosphate-dehydrogenase (GAPDH). GAPDH served as a reference gene, since its expression is widely recognised for standardising the expression levels of different genes in various tissues and under a number of physiological conditions, including muscle injury and repair $[18,19]$. Reverse transcription was performed at $50^{\circ} \mathrm{C}$ for $30 \mathrm{~min}$ prior to cycling. Linear amplification was undertaken according to the studied gene, after 28-39 cycles (table 1). Each cycle consisted of $1 \mathrm{~min}$ at $94^{\circ} \mathrm{C}$, followed by $1 \mathrm{~min}$ at $55^{\circ} \mathrm{C}$ and $3 \mathrm{~min}$ at $68^{\circ} \mathrm{C}$. Co-amplification was achieved by adding GAPDH primers to the reaction mixtures with 28 cycles remaining. Cycling was then stopped for $5 \mathrm{~min}$ at $55^{\circ} \mathrm{C}$ to allow the reverse transcription of GAPDH-specific sequences, and the remaining 28 amplification cycles were resumed. The last cycle had an elongation segment of $10 \mathrm{~min}$ instead of $3 \mathrm{~min}$. In the current authors' experience, the reverse transcriptase in this kit is very temperature stable. All RT-PCR products were separated by electrophoresis in $1.5 \%$ standard agarose $/ 1 \times$ Tris-borate ethylenediamine tetraacetic acid buffer (TBE) gels and stained with ethidium bromide, except for MHC/GAPDH co-amplifications, which were separated in 3\% high-resolution (3:1) agarose $/ 1 \times \mathrm{TBE}$ gels.

\section{Densitometric analysis}

Amplification products were analysed in the Alpha Imager 2000 Documentation and Analysis System (Alpha Inotech Corporation, San Leandro, CA, USA). mRNA expressions of the different molecular markers were normalised in the injured fibres relative to GAPDH mRNA. Therefore, the intensity of the band representing the target gene from each sample was divided by the intensity of the sample's corresponding GAPDH band. The ratios calculated in the treated diaphragms were then compared to those obtained for noninjured control tissues and plotted against time in terms of relative expression. 


\begin{tabular}{|c|c|c|c|c|}
\hline Gene & 5' Primer & 3' Primer & Cycles & bp size \\
\hline p94 & 5'CTCTCCTTCTGGTCTGAACATGGG3' & 5'GTGACGGTCTGTCATCTGAGGCC3' & 32 & 115 \\
\hline cFos & 5'CACCGACCTGCCTGCAAGATC3' & 5'AGCTCAGTGAGTCAGAGGAGG3' & 35 & 523 \\
\hline Myogenin & 5'ACСTTCСTGTCCACСTTCAGG3' & 5'AGCAAATGATCTCCTGGGTTG3' & 36 & 498 \\
\hline IGF-II & 5'CCGGCTTCCAGGTACCAATGG3' & 5'TTGGGTGGTAACACGATCAGG3' & 35 & 508 \\
\hline MHC & 5'CCGCATTGAGGAGCTGGAGG3' & 5'CTCTCCACACTGCTGGAGAGG3' & 33 & 314 \\
\hline Titin & 5'TGTCTGCCCCTGCAACGGTC3' & 5'TTCCACCACAGCAGTGGCCC3' & 33 & 581 \\
\hline
\end{tabular}

Reverse transcription was performed at $50^{\circ} \mathrm{C}$. PCR amplification conditions were denaturation at $94^{\circ} \mathrm{C}$ for 1 min, annealing at $55^{\circ} \mathrm{C}$ for 1 min, and elongation at $68^{\circ} \mathrm{C}$ for 3 min. bp: base pairs; GAPDH: glyceraldehyde-3-phosphate-dehydrogenase; p94: calpain 94; bFGF: basic fibroblast growth factor; IGF: insulin-like growth factor; MHC: myosin heavy chain.

\section{Statistical analysis}

Values are expressed as the means of relative expression \pm SEM. The relative mRNA expression of each factor at different time points and the abnormal muscle fraction area in the injured hemidiaphragm were first compared with the contralateral hemidiaphragm by the Wilcoxon test for related samples. The expression of each factor at different time points was compared by one-way ANOVA, when normality and equality of variance were confirmed. The Bonferroni post hoc test was applied to locate significant differences between different time points. Otherwise, Kruskal-Wallis one-way ANOVA was used on ranks. The level of significance was $\mathrm{p}<0.05$.

\section{RESULTS}

\section{Histological quantification of abnormal muscle area}

Necrosis and inflammation progression were monitored by H\&E staining in both injured and control hemidiaphragms (fig. 1). Control muscles did not show any monocyte/ macrophage infiltration (fig. 1a). Moderate inflammatory cells infiltration appeared as early as $6 \mathrm{~h}$ PI, but was more evident at $24 \mathrm{~h}$ (fig. 1b). Muscle necrosis with abnormal morphology and infiltration of swollen necrotic cells by mononucleated cells reached a maximum at 48 (fig. 1c) and $72 \mathrm{~h}$ PI. These anomalies declined subsequently by $96 \mathrm{~h}$, and disappeared completely at $240 \mathrm{~h}$ PI (fig. 1d). Statistical comparisons are shown in figure 2.

\section{Time-course expression of markers}

Proteases

p94 mRNA peaked at $1 \mathrm{~h}$ after diaphragm injury to twice the baseline value $(\mathrm{p}<0.05)$ and decreased to baseline at $4 \mathrm{~h}$. A late significant increase was observed at $240 \mathrm{~h}$ PI (fig. 3a).

\section{Transcription factors}

cFos mRNA expression was decreased at $6 \mathrm{~h}$ PI, compared with the control side $(\mathrm{p}<0.05)$, and returned to baseline at $12 \mathrm{~h}$ PI (fig. 3b). Thereafter, it started to rise progressively up to $48 \mathrm{~h} \mathrm{PI}$, and increased sharply with a peak at $96 \mathrm{~h}$ PI $(\mathrm{p}<0.05)$. Interestingly, the beginning of cFos mRNA elevation coincided directly with decreasing myogenin mRNA (72 h PI). Myogenin mRNA expression began to rise at $12 \mathrm{~h}$ PI $(\mathrm{p}<0.05)$, and peaked at $48 \mathrm{~h}$ with a value three-fold higher than that of the controls $(p<0.05)$. Its expression remained significantly high until 72 h PI (fig. 3c).

\section{Growth factors}

IGF-II mRNA expression declined by $1 \mathrm{~h}$ PI and reached a minimum level at $6 \mathrm{~h}(\mathrm{p}<0.05)$, remaining low until $48 \mathrm{~h}$ PI. Its maximal level was observed at $72 \mathrm{~h}$ of recovery and was almost twice as high as that of the contralateral hemidiaphragm $(p<0.05)$, with significant elevation until $240 \mathrm{~h}$ PI (fig. 3d). bFGF mRNA expression dropped initially at $6 \mathrm{~h}$ PI $(p<0.05)$, and increased significantly at $24 \mathrm{~h}$ PI $(\mathrm{p}<0.05)$. A second peak of expression, two-fold higher than in the control diaphragm, was noted at $96 \mathrm{~h}$ PI $(\mathrm{p}<0.05)$, reaching baseline at 240 h PI (fig. 3e).

\section{Structural proteins}

MHC mRNA expression showed initial depression at $1 \mathrm{~h}$ PI $(\mathrm{p}<0.05)$, and increased significantly at $72 \mathrm{~h}$ PI (fig. 4a). Maximal expression was reached at $96 \mathrm{~h}$ PI and remained high thereafter $(\mathrm{p}<0.05)$. After an initial drop that was not significant, titin mRNA expression rose significantly by $72 \mathrm{~h}$ PI and stayed elevated thereafter $(p<0.05$; fig. $4 b)$.

\section{DISCUSSION}

The main findings of the present study are as follows: 1) p94 expression levels peaked significantly at $1 \mathrm{~h}$ PI; 2) after an initial decrease, the mRNA levels of the transcription factor cFos started to rise, and peaked at $96 \mathrm{~h}$ PI, while myogenin mRNA levels increased as early as $12 \mathrm{~h}$ PI; 3) IGF-II levels decreased initially until $48 \mathrm{~h}$ PI and climbed thereafter, with a peak at $72 \mathrm{~h} \mathrm{PI}$;) after an initial drop, bFGF mRNA levels reached a maximum at $96 \mathrm{~h} \mathrm{PI}$; and 5) mRNA levels of both MHC and titin increased significantly at $72 \mathrm{~h}$ PI. Table 2 summarises these data.

\section{Histological findings}

In a previous study, it was reported that local application of caffeine induces reproducible rat diaphragm sarcolemmal damage peak at $1 \mathrm{~h}$ PI, concomitant to maximal loss of force [2]. Actually, and even though H\&E is not truly specific for 

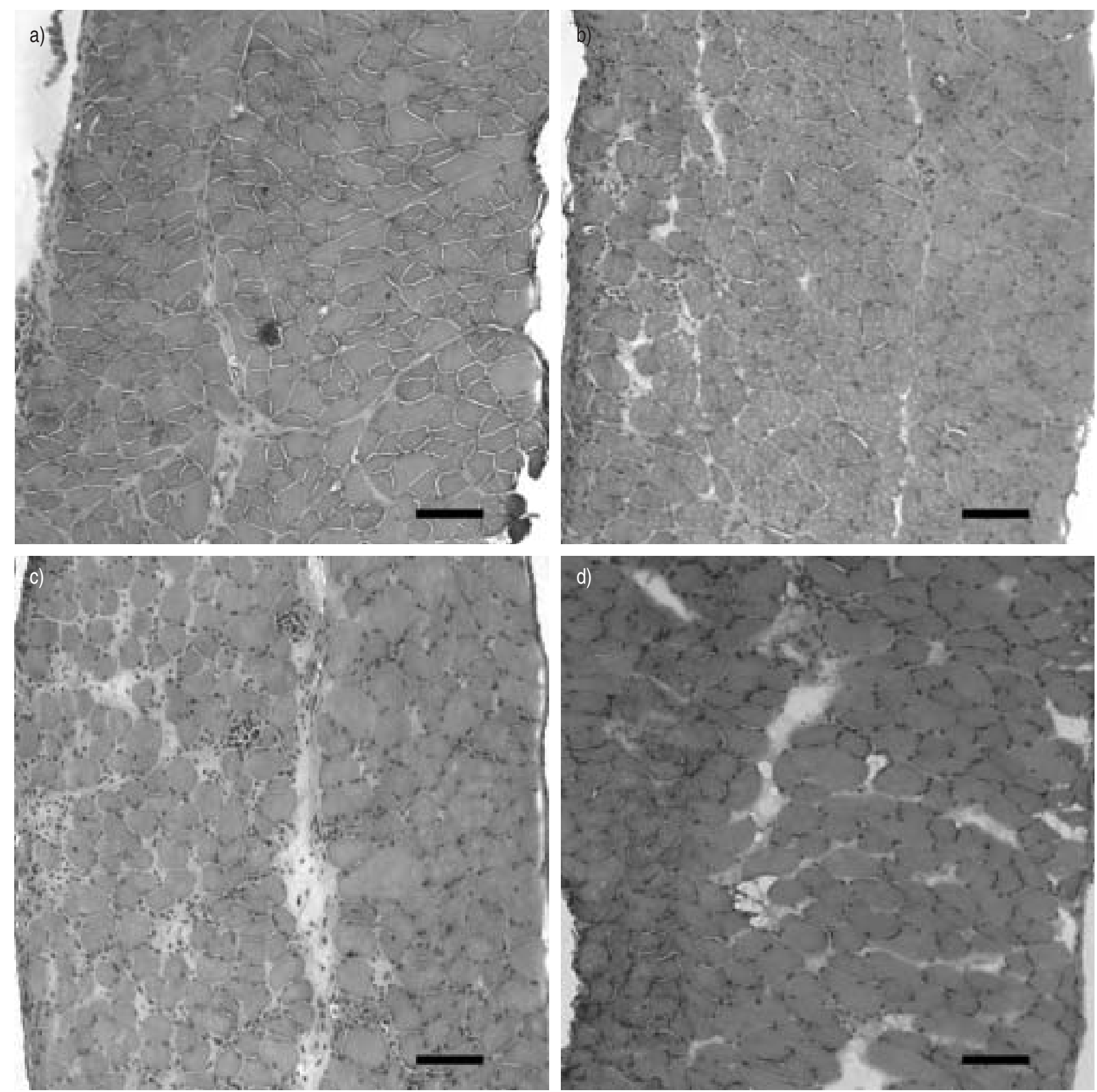

FIGURE 1. Control nontreated diaphragm (a). The interstitial space and myocyte invasion by mononucleated cells was evident at $24 \mathrm{~h}$ post-injury (PI; b), and rose significantly at $48 \mathrm{~h} \mathrm{PI} \mathrm{(c).} \mathrm{Mononucleated} \mathrm{cell} \mathrm{infiltration} \mathrm{disappeared} \mathrm{completely} \mathrm{at} 240 \mathrm{~h}$ PI (d). Scale bars $=50 \mu \mathrm{m}$.

inflammatory processes, and did not allow the current authors to differentiate the inflammatory cell population, it was shown that PI inflammatory infiltrates appear later than myocyte membrane injury, and are substantial only at $48-72 \mathrm{~h}$ PI. The role of inflammatory infiltrate remains to be determined, and it is not excluded that inflammation could contribute to the activation of molecular factors involved in the muscle repair process [20-22]. LAPOINTE et al. [23] suggest that nonsteroidal anti-inflammatory drugs inhibit the repair process following muscle injury.

\section{Pattern of gene activation}

\section{Proteases}

p94, an indispensable, muscle-specific, calcium-dependent, nonlysosomal cysteine protease [24], modulates the function of digesting proteases [25]. Calpains are activated during sepsis-induced muscle injury [26] and resistive loadinginduced diaphragm damage $[6,16]$. In contrast to the other factors, p94 mRNA did not decrease, but peaked transiently and immediately after injury, simultaneously with maximum sarcolemmal injury and loss of force [2]. This rapid increase 


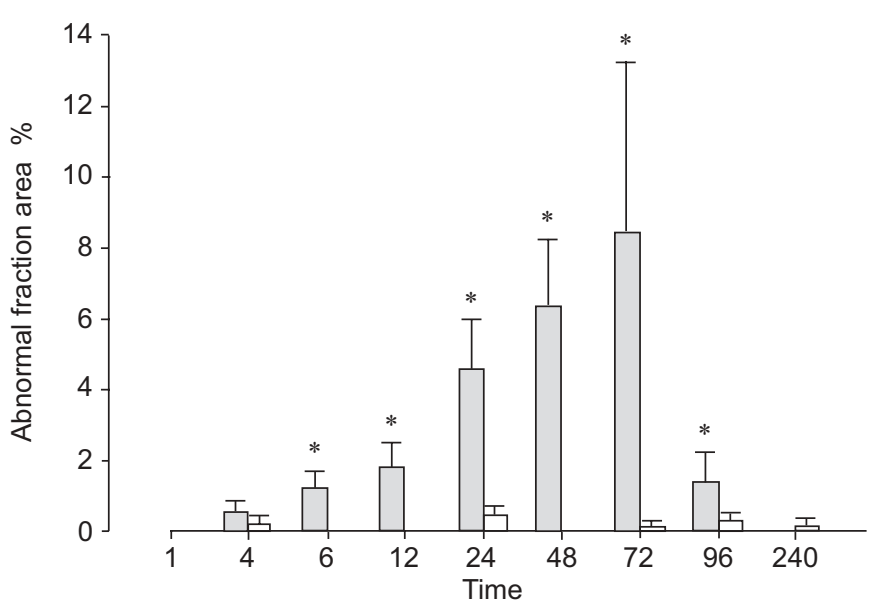

FIGURE 2. Evolution of the haematoxylin and eosin histological abnormalities in caffeine-treated $(\square)$ and nontreated control hemidiaphragms $(\square)$. The results are expressed as percentages \pm SEM of the total area for each post-injury time point. Bars are not represented when no infiltration was observed. ${ }^{*}: p<0.05$, significantly different from controls.

suggests that the immediate caffeine-induced rise of intracellular calcium could have triggered p94 mRNA upregulation. Even though quantification of the level of enzyme activation was not possible, because of the small quantity of tissue, it is reasonable to assume that the p94 mRNA peak promoted the enzyme's synthesis and led to larger availability of its activated form. In addition, calpains are implicated in cell migration and signalling [27], myoblast fusion, and myogenin expression [28].

\section{Transcription factors}

The proto-oncogene cFos promotes muscle cell repair and hypertrophy in immediate response to both injury [29] and mechanical stress $[30,31]$, while myogenin is a potent regulator of terminal muscle differentiation during myogenesis and regeneration [32-34]. Unexpectedly, myogenin rose as early as $12 \mathrm{~h}$ PI, whereas cFos increased later than expected at $72 \mathrm{~h}$ PI. This coincided with decreased myogenin transcripts, perhaps because myogenin inhibits the cFos promoter [35]. In addition, the highest levels of inflammation coincided with elevated cFos and, thus, indicated a potential role of some proinflammatory factors in inducing cFos expression and mpc division [36, 37]. As a terminal differentiation marker, late expression of the myogenin gene was expected. Nonetheless, some studies of crush injury or toxic damage in peripheral muscles have detected early myogenin mRNA and protein expression in the myonuclei/nuclei of satellite cells [29, 38, 39]. This implies the existence of a subpopulation of committed satellite cells that immediately begin terminal differentiation without previous mitosis, whereas other mpc proliferate and differentiate only thereafter [40]. These highly radiationresistant satellite cells, which retain the ability to form muscle in the short term and go directly to terminal differentiation [40], might be present in the diaphragm.

\section{Growth factor transcripts}

bFGF and IGF-II increased at 24 and $72 \mathrm{~h}$ PI, respectively. bFGF, a strong mitogenic factor [41], enhances muscle regeneration [42] and myogenic cell migration [43]. Diaphragm bFGF expression is not well known. It is enhanced by hypoxiainduced hyperventilation [44] and is decreased in mdx mice
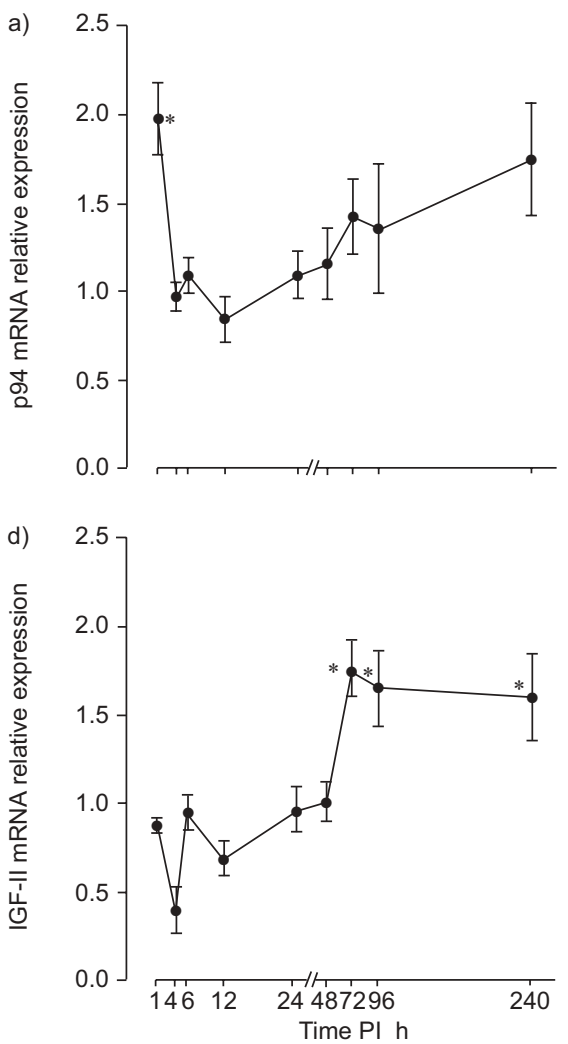
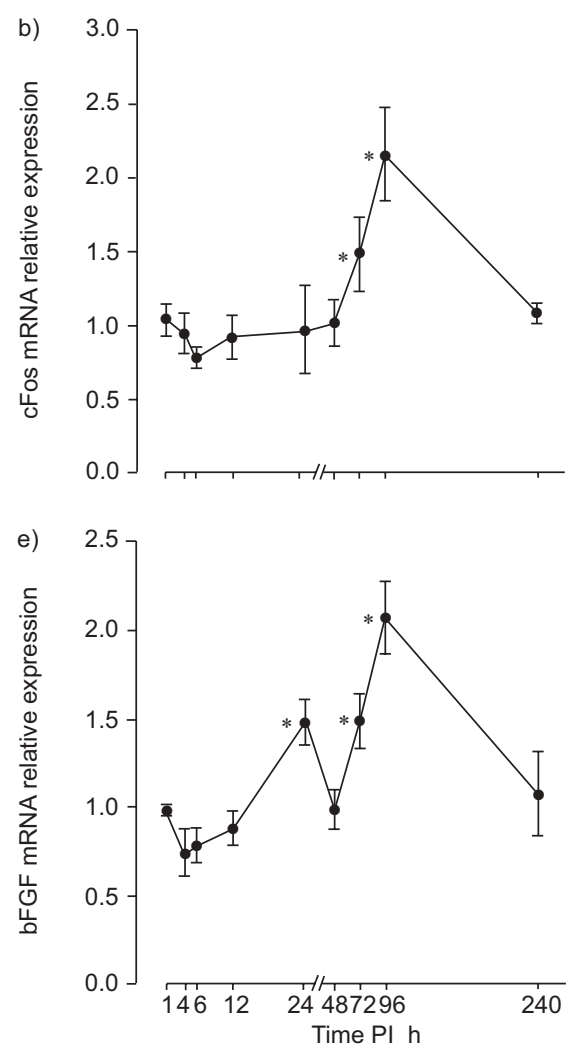

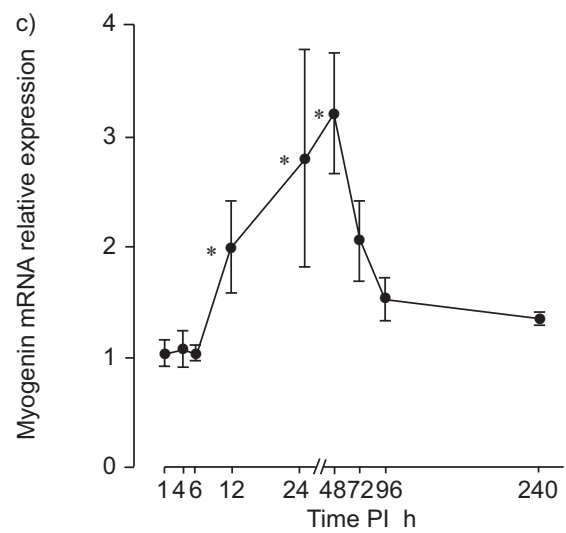

FIGURE 3. Post-injury (PI) expression patterns of calpain 94 (p94; a), myogenic transcription factors cFos (b) and myogenin (c), and growth factors insulin-like growth factor (IGF)-II (d) and basic fibroblast growth factor (bFGF; e). Relative expression \pm SEM compared with the control is shown for each time point (the mean of mRNA expression in the control diaphragm was set at 1 , and PI mRNA expression values were normalised to the control). ${ }^{*}: p<0.05$ (mRNA expression in the treated hemidiaphragms was significantly different from the controls). 

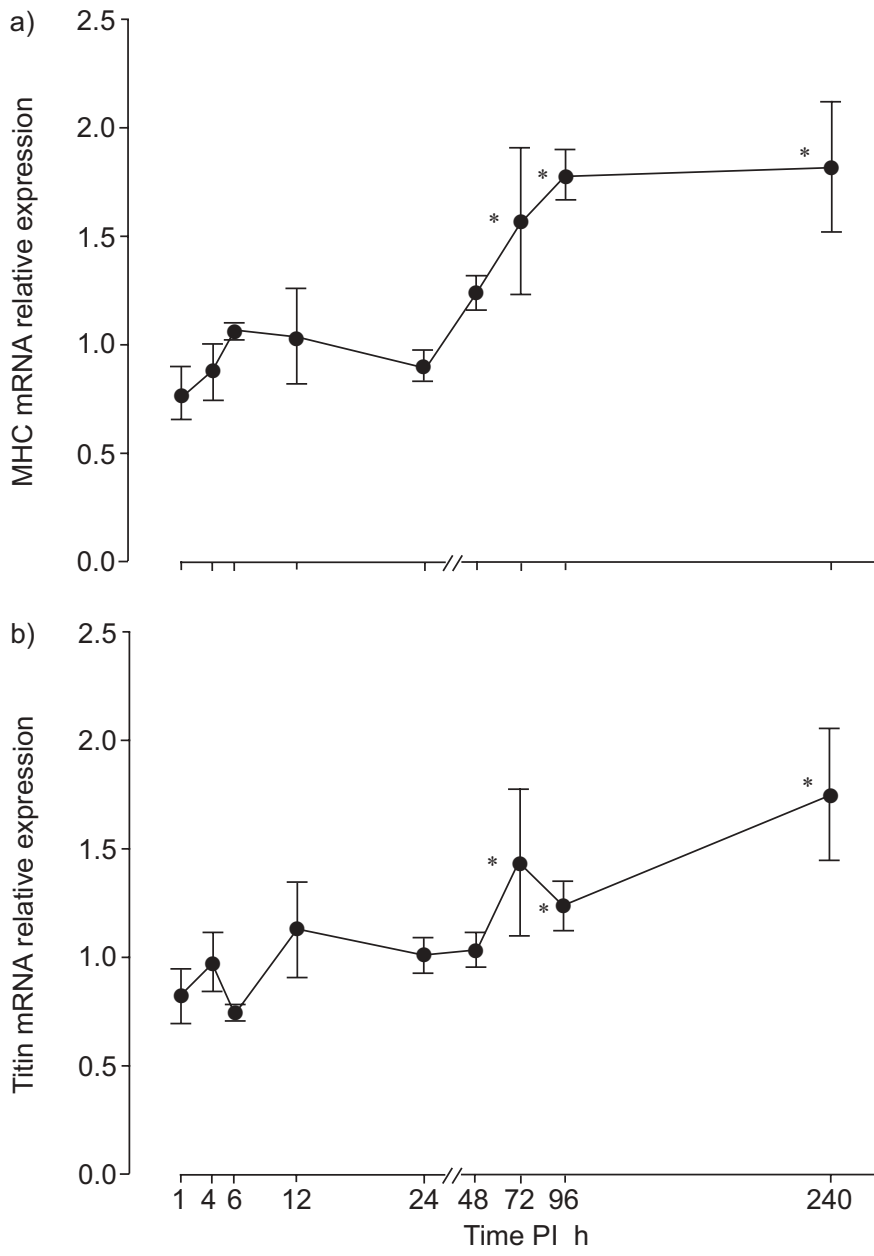

FIGURE 4. Post-injury (PI) mRNA expression patterns of the muscle structural proteins myosin heavy chain (MHC; a) and titin (b). Relative expression \pm SEM compared with the control is shown for each time point (the mean of mRNA expression in the control diaphragm was set at 1 , and PI mRNA expression values were normalised to the control). ${ }^{*}: p<0.05$ (mRNA expression in the treated hemidiaphragms was significantly different from the controls).

[45]. The current authors found that the rise in bFGF mRNA lasted $96 \mathrm{~h} \mathrm{PI}$, confirming the involvement of bFGF in the diaphragmatic repair programme. IGF-II acts as a signalling factor during muscle repair [46], activating mpc proliferation and terminal differentiation [47]. Very little is known about IGF-II expression and action in the diaphragm. Although IGFs appear to be involved in diaphragm remodelling, most of the available data concern IGF-I. IGF-II increases diaphragmatic specific force [48], enhances fibre growth, maintains their size $[49,50]$, and prevents corticosteroid-induced diaphragm atrophy in emphysematous hamsters [51]. Conversely, IGF-I and -II expression is decreased in the rat diaphragm after massive corticosteroid treatment [52]. According to the current data, IGF-II transcripts are upregulated during the repair process in the diaphragm. Moreover, IGF-II mRNA increases only after myogenin gene activation, as demonstrated in myogenesis models [47]. IGF-II mRNA elevation precedes structural protein transcript expression, and is maintained at high levels during MHC and titin transcript expression and force recovery [2]. This points to IGF-II involvement in structural protein construction, and is interesting in light of a recent study showing that it promotes skeletal muscle force and myofibre heterogeneity [53].

Finally, the late increase of MHC and titin mRNA, concomitant with inflammatory infiltration withdrawal and functional recovery [2], confirms the efficiency of the diaphragmatic repair process. The earlier rise of MHC mRNA suggests that contractile protein gene activation precedes noncontractile protein genes like titin. Maximal expression of titin transcripts, an elastic protein considered to be a molecule that helps to position myosin filaments in sarcomeres [54], was observed only at $240 \mathrm{~h}$ PI.

\section{Study limitations}

Caffeine-induced injury model

Caffeine-induced damage is not a model of physiological injury in its classic sense. Nonetheless, the current authors' preference for the caffeine model of muscle injury in the present study was two-fold: 1) it has already been demonstrated that local application of a caffeine solution elicits reproducible diaphragm sarcolemmal injury in association with a major reduction of diaphragm force [2]; and 2) diaphragm exposure to caffeine produces injury without interference of other factors prone to muscle fibre injury, such as hypoxia and acidosis, as seen in resistive-loading models

\section{TABLE 2 Post-injury gene expression profile}

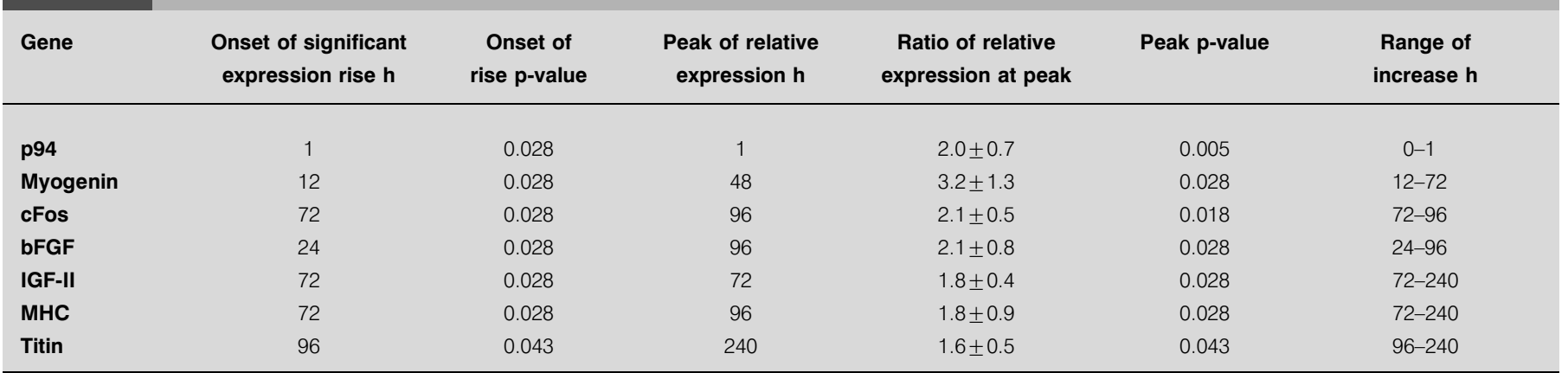

Statistical analyses were performed as described in Materials and methods. The rise is considered significant compared with the control side at p<0.05. p94: calpain 94 bFGF: basic fibroblast growth factor; IGF: insulin-like growth factor; MHC: myosin heavy chain. 
[16]. Hence, the eloquence of caffeine-induced injury is that it eliminates several confounding factors. Furthermore, skeletal muscle caffeine exposure has been shown to stimulate $\mathrm{Ca}^{2+}$ release from the sarcoplasmic reticulum by activating ryanodine receptors, thereby increasing intracellular $\mathrm{Ca}^{2+}$ concentrations [55]. The massive elevation of intracellular calcium is a known contributor to muscle injury. Several studies suggest that caffeine-induced calcium release from intracellular stores can induce mammalian sarcolemmal damage [56] and myofilament degradation [57].

H\&E staining allowed the assessment of histological damage. As mentioned previously, this technique does not allow specific differentiation of inflammatory cell types, but clearly shows cell infiltration (fig. 1).

\section{RT-PCR}

The current study was designed to screen and monitor the time course of gene expression of several factors involved in myocyte regeneration after diaphragmatic damage. RT-PCR was the most appropriate technique for the detection of small mRNA quantities of the selected factors, since the amount of injured tissue obtained from the rat diaphragm was very limited. Although RT-PCR does not give information about the presence, amount or location of the resulting proteins, significant modifications of mRNA levels are both reproducible and informative with respect to PI activation of the genes involved. The suitability of GAPDH as a housekeeping gene is exemplified by the internal consistency of the current results. The different temporal gene expression patterns that emerged from the current data were possible because GAPDH expression levels remained constant throughout the PI period covered by the study.

\section{Conclusions}

In summary, the current authors conclude that caffeineinduced injury triggers a time-based programme of the expression of a variety of genes, at least in the rat diaphragm, tailored to meet the needs of muscle repair. The pattern of expression of these genes covers a wide range of different phenomena involved in complete muscle repair, which go from the proteolysis of damaged muscle proteins to the synthesis of new muscle fibres. Future studies are required to elucidate the exact pattern of gene expression in the muscle repair process under other chronic conditions of diaphragm injury, such as sepsis and chronic obstructive pulmonary disease.

\section{ACKNOWLEDGMENTS}

The authors would like to thank O. Da Silva (Research Support Office, CHUM Research Centre, Hôtel-Dieu Hospital, Montréal, QC, Canada) for his editorial assistance.

\section{REFERENCES}

1 Jiang TX, Reid WD, Road JD. Delayed diaphragm injury and diaphragm force production. Am J Respir Crit Care Med 1998; 157: 736-742.

2 Hayot M, Barreiro E, Perez A, Czaika G, Comtois AS, Grassino AE. Morphological and functional recovery from diaphragm injury: an in vivo rat diaphragm injury model. J Appl Physiol 2001; 90: 2269-2278.

3 Zhu E, Comtois AS, Fang L, Comtois NR, Grassino AE. Influence of tension time on muscle fiber sarcolemmal injury in rat diaphragm. J Appl Physiol 2000; 88: 135-141.

4 Reid WD, Huang J, Bryson S, Walker DC, Belcastro AN. Diaphragm injury and myofibrillar structure induced by resistive loading. J Appl Physiol 1994; 76: 176-184.

5 Zhu E, Petrof BJ, Gea J, Comtois N, Grassino AE. Diaphragm muscle fiber injury after inspiratory resistive breathing. Am J Respir Crit Care Med 1997; 155: 1110-1116.

6 Jiang TX, Reid WD, Belcastro A, Road JD. Load dependence of secondary diaphragm inflammation and injury after acute inspiratory loading. Am J Respir Crit Care Med 1998; 157: 230-236.

7 Lin MC, Ebihara S, El Dwairi Q, et al. Diaphragm sarcolemmal injury is induced by sepsis and alleviated by nitric oxide synthase inhibition. Am J Respir Crit Care Med 1998; 158: 1656-1663.

8 Gayan-Ramirez G, Decramer M. Effects of mechanical ventilation on diaphragm function and biology. Eur Respir J 2002; 20: 1579-1586.

9 Bernard N, Matecki S, Py G, Lopez S, Mercier J, Capdevila X. Effects of prolonged mechanical ventilation on respiratory muscle ultrastructure and mitochondrial respiration in rabbits. Intensive Care Med 2003; 29: 111-118.

10 Orozco-Levi M, Lloreta J, Minguella J, Serrano S, Broquetas JM, Gea J. Injury of the human diaphragm associated with exertion and chronic obstructive pulmonary disease. Am J Respir Crit Care Med 2001; 164: 1734-1739.

11 Macgowan NA, Evans KG, Road JD, Reid WD. Diaphragm injury in individuals with airflow obstruction. Am J Respir Crit Care Med 2001; 163: 1654-1659.

12 Armstrong RB. Initial events in exercise-induced muscular injury. Med Sci Sports Exerc 1990; 22: 429-435.

13 Grounds MD. Muscle regeneration: molecular aspects and therapeutic implications. Curr Opin Neurol 1999; 12: 535-543.

14 Hawke TJ, Garry DJ. Myogenic satellite cells: physiology to molecular biology. J Appl Physiol 2001; 91: 534-551.

15 Grounds MD, White JD, Rosenthal N, Bogoyevitch MA. The role of stem cells in skeletal and cardiac muscle repair. J Histochem Cytochem 2002; 50: 589-610.

16 Reid WD, Belcastro AN. Time course of diaphragm injury and calpain activity during resistive loading. Am J Respir Crit Care Med 2000; 162: 1801-1806.

17 Davey DF. Point counting techniques, 2002. www.physiol. usyd.edu.au/daved/teaching/emu/point_counting.html. Date last accessed: October 31 2004. Date last updated: April 102002.

18 Biolo G, Bosutti A, Iscra F, Toigo G, Gullo A, Guarnieri G. Contribution of the ubiquitin-proteasome pathway to overall muscle proteolysis in hypercatabolic patients. Metabolism 2000; 49: 689-691.

19 Gedrange T, Luck O, Hesske G, Buttner C, Seibel P, Harzer W. Differential expression of myosin heavy-chain mRNA in muscles of mastication during functional advancement of the mandible in pigs. Arch Oral Biol 2001; 46: 215-220.

20 Robertson TA, Maley MA, Grounds MD, Papadimitriou JM. The role of macrophages in skeletal 
muscle regeneration with particular reference to chemotaxis. Exp Cell Res 1993; 207: 321-331.

21 Lescaudron L, Peltekian E, Fontaine-Perus J, et al. Blood borne macrophages are essential for the triggering of muscle regeneration following muscle transplant. Neuromuscul Disord 1999; 9: 72-80.

22 Hirata A, Masuda S, Tamura T, et al. Expression profiling of cytokines and related genes in regenerating skeletal muscle after cardiotoxin injection: a role for osteopontin. Am J Pathol 2003; 163: 203-215.

23 Lapointe $\mathrm{BM}$, Fremont $\mathrm{P}$, Cote $\mathrm{CH}$. Adaptation to lengthening contractions is independent of voluntary muscle recruitment but relies on inflammation. Am J Physiol Regul Integr Comp Physiol 2002; 282: R323-R329.

24 Belcastro AN, Shewchuk LD, Raj DA. Exercise-induced muscle injury: a calpain hypothesis. Mol Cell Biochem 1998; 179: 135-145.

25 Sorimachi H, Ishiura S, Suzuki K. Structure and physiological function of calpains. Biochem J 1997; 328: 721-732.

26 Williams AB, Decourten-Myers GM, Fischer JE, Luo G, Sun $X$, Hasselgren PO. Sepsis stimulates release of myofilaments in skeletal muscle by a calcium-dependent mechanism. FASEB J 1999; 13: 1435-1443.

27 Perrin BJ, Huttenlocher A. Calpain. Int J Biochem Cell Biol 2002; 34: 722-725.

28 Dedieu S, Dourdin N, Dargelos E, et al. Calpain and myogenesis: development of a convenient cell culture model. Biol Cell 2002; 94: 65-76.

29 Kami K, Noguchi K, Senba E. Localization of myogenin, cfos, c-jun, and muscle-specific gene mRNAs in regenerating rat skeletal muscle. Cell Tissue Res 1995; 280: 11-19.

30 Puntschart A, Wey E, Jostarndt $\mathrm{K}$, et al. Expression of fos and jun genes in human skeletal muscle after exercise. $A m \mathrm{~J}$ Physiol 1998; 274: C129-C137.

31 Grembowicz KP, Sprague D, McNeil PL. Temporary disruption of the plasma membrane is required for c-fos expression in response to mechanical stress. Mol Biol Cell 1999; 10: 1247-1257.

32 Yablonka-Reuveni Z, Rivera AJ. Temporal expression of regulatory and structural muscle proteins during myogenesis of satellite cells on isolated adult rat fibers. Dev Biol 1994; 164: 588-603.

33 Perry RL, Rudnicki MA. Molecular mechanisms regulating myogenic determination and differentiation. Front Biosci 2000; 5: D750-D767.

34 Launay T, Armand AS, Charbonnier F, et al. Expression and neural control of myogenic regulatory factor genes during regeneration of mouse soleus. J Histochem Cytochem 2001; 49: 887-899.

35 Trouche D, Masutani H, Groisman R, Robin P, Lenormand JL, Harel-Bellan A. Myogenin binds to and represses c-fos promoter. FEBS Lett 1995; 361: 140144.

36 Hermann GE, Rogers RC, Bresnahan JC, Beattie MS. Tumor necrosis factor-alpha induces cFOS and strongly potentiates glutamate-mediated cell death in the rat spinal cord. Neurobiol Dis 2001; 8: 590-599.

$37 \mathrm{Li}$ YP. TNF-alpha is a mitogen in skeletal muscle. Am J Physiol Cell Physiol 2003; 285: C370-C376.

38 Grounds MD, Garrett KL, Lai MC, Wright WE, Beilharz MW. Identification of skeletal muscle precursor cells in vivo by use of MyoD1 and myogenin probes. Cell Tissue Res 1992; 267: 99-104.

39 Rantanen J, Hurme T, Lukka R, Heino J, Kalimo H. Satellite cell proliferation and the expression of myogenin and desmin in regenerating skeletal muscle: evidence for two different populations of satellite cells. Lab Invest 1995; 72: 341-347.

40 Heslop L, Morgan JE, Partridge TA. Evidence for a myogenic stem cell that is exhausted in dystrophic muscle. J Cell Sci 2000; 113: 2299-2308.

41 Anderson JE, Mitchell CM, McGeachie JK, Grounds MD. The time course of basic fibroblast growth factor expression in crush-injured skeletal muscles of SJL/J and BALB/ c mice. Exp Cell Res 1995; 216: 325-334.

42 Menetrey J, Kasemkijwattana C, Day CS, et al. Growth factors improve muscle healing in vivo. J Bone Joint Surg $\mathrm{Br}$ 2000; 82: 131-137.

43 Webb SE, Lee KK, Tang MK, Ede DA. Fibroblast growth factors 2 and 4 stimulate migration of mouse embryonic limb myogenic cells. Dev Dyn 1997; 209: 206-216.

44 Siafakas NM, Jordan M, Wagner H, Breen EC, Benoit H, Wagner PD. Diaphragmatic angiogenic growth factor mRNA responses to increased ventilation caused by hypoxia and hypercapnia. Eur Respir J 2001; 17: 681687.

45 Anderson JE, Garrett K, Moor A, McIntosh L, Penner K. Dystrophy and myogenesis in $\mathrm{mdx}$ diaphragm muscle. Muscle Nerve 1998; 21: 1153-1165.

46 Wilson EM, Hsieh MM, Rotwein P. Autocrine growth factor signaling by insulin-like growth factor-II mediates MyoD-stimulated myocyte maturation. J Biol Chem 2003; 278: 41109-41113.

47 Rosen KM, Wentworth BM, Rosenthal N, Villa-Komaroff L. Specific, temporally regulated expression of the insulinlike growth factor II gene during muscle cell differentiation. Endocrinology 1993; 133: 474-481.

48 Gregorevic P, Plant DR, Leeding KS, Bach LA, Lynch GS. Improved contractile function of the $\mathrm{mdx}$ dystrophic mouse diaphragm muscle after insulin-like growth factorI administration. Am J Pathol 2002; 161: 2263-2272.

49 Gayan-Ramirez G, de Paepe K, Cadot P, Decramer M. Detrimental effects of short-term mechanical ventilation on diaphragm function and IGF-I mRNA in rats. Intensive Care Med 2003; 29: 825-833.

50 Lewis MI, Li H, Huang ZS, Biring MS, Cercek B, Fournier M. Influence of varying degrees of malnutrition on IGF-I expression in the rat diaphragm. J Appl Physiol 2003; 95: 555-562.

51 Fournier M, Huang ZS, Li H, Da X, Cercek B, Lewis MI. Insulin-like growth factor I prevents corticosteroidinduced diaphragm muscle atrophy in emphysematous hamsters. Am J Physiol Regul Integr Comp Physiol 2003; 285: R34-R43.

52 Gayan-Ramirez G, Vanderhoydonc F, Verhoeven G, Decramer M. Acute treatment with corticosteroids decreases IGF-1 and IGF-2 expression in the rat diaphragm and gastrocnemius. Am J Respir Crit Care Med 1999; 159: 283-289.

53 McLoon LK, Christiansen SP. Increasing extraocular muscle strength with insulin-like growth factor II. Invest Ophthalmol Vis Sci 2003; 44: 3866-3872. 
54 Schiaffino S, Reggiani C. Molecular diversity of myofibrillar proteins: gene regulation and functional significance. Physiol Rev 1996; 76: 371-423.

55 Allen DG, Westerblad $H$. The effects of caffeine on intracellular calcium, force and the rate of relaxation of mouse skeletal muscle. J Physiol 1995; 487: 331-342.
56 Duncan CJ. Role of intracellular calcium in promoting muscle damage: a strategy for controlling the dystrophic condition. Experientia 1978; 34: 1531-1535.

57 Duncan CJ, Smith JL. Action of caffeine in initiating myofilament degradation and subdivision of mitochondria in mammalian skeletal muscle. Comp Biochem Physiol C 1980; 65: 143-145. 